\title{
T. S. ELIOT'S “OLD POSSUM'S BOOK OF PRACTICAL CATS” IN THE CONTEXT OF “NURSERY RHYMES” TRADITION
}

\author{
Kristina M. Marshaniya \\ Tyumen State University (Tyumen, Russia) \\ ORCID ID: https://orcid.org/0000-0003-0218-0079
}

\begin{abstract}
A bstract. This paper presents the results of a comparative study of the collection of poems Old Possum's Book of Practical Cats (1939) by T. S. Eliot and the collection of children's verses Mother Goose Old Nursery Rhymes (published in 1760), compiled and illustrated by A. Rackham (1913). Consisting of 15 poems, and distinguished by its frivolity against the background of other works by Eliot, the cycle Old Possum's Book of Practical Cats has been overlooked by both Russian and foreign researchers for a long time. Recently a surge of interest in this book of verse has been provoked by the release of a feature film Cats (2019) based on the world-famous musical by Andrew Lloyd Webber. This fact as well as the lack of serious academic studies of Eliot's book of verse has determined the urgency and novelty of this paper. It is also important to show the involvement of this segment of Eliot's poetry into the English literary tradition. The aim of this research is to identify the influence of Victorian aesthetics of nonsense on the poetry of T. S. Eliot's cycle. The method of comparative analysis has been chosen as the main research method. Besides, structural-semantic and linguistic-cultural methods have been used. In understanding and interpreting the term "tradition" the author relies on Eliot's aesthetics, in which this concept is central. The terminological unit "nursery rhymes" is used in its original traditional meaning since its historical and cultural background disappears in any Russian translation or scholarly interpretation. In the course of work, certain features of nursery rhymes have been identified in the poetic texts by the great Modernist. The study of the specificity of this genre (the playful atmosphere of the text, the special rhythms and forms of coding historical events, animalistic perspectives, the use of various repetitions and imitations, the creation of author's occasionalisms and unusual names of characters, etc.) confirms strong influence of the tradition of English nursery rhymes on T. S. Eliot's works.
\end{abstract}

Keywords: animal studies; poetic cycles; refrain; limerick; comparative studies; literary genres; literary creative activity.

\section{«ПОПУЛЯРНАЯ НАУКА О КОШКАХ, НАПИСАННАЯ СТАРЫМ ОПОССУМОМ» T. С. ЭЛИОТА В КОНТЕКСТЕ ТРАДИЦИИ «NURSERY RHYMES»}

\author{
Маршания К. М. \\ Тюменский государственный университет (Тюмень, Россия) \\ ORCID ID: https://orcid.org/0000-0003-0218-0079
}

\begin{abstract}
Аннотаиия. В данной работе представлены результаты сравнительного исследования поэтического цикла «Популярная наука о кошках, написанная Старым Опоссумом» Т. С. Элиота (1939) и сборника стихов для детей «Песни Матушки Гусыни» (опубл. в 1760), составленного и проиллюстрированного А. Рэкхемом (1913). Поэтический цикл «Популярная наука о кошках, написанная Старым Опоссумом», состоящий из 15 стихотворений и выделяющийся своей несерьезностью на фоне остальных произведений Элиота, долгое время был обделен вниманием как российских, так и зарубежных исследователей-элиотоведов. Всплеск интереса к данному произведению в последнее время спровоцирован выходом на мировые экраны художественного фильма «Кошки» (2019), снятого по мотивам одноименного мюзикла Э. Л. Уэббера. Этот факт, а также отсутствие серьезных академических исследований цикла определяют актуальность и новизну данной работы. Также важным представляется показать включенность этого сегмента поэзии Элиота в английскую литературную традицию. Целью данной работы является выявление влияния эстетики викторианского нонсенса на поэтический цикл Т. С. Элиота. В качестве основного метода исследования был выбран метод сравнительно-сопоставительного анализа, а также использованы структурно-семантический и лингвокультурологический методы. В понимании и интерпретации термина «традиция» мы опираемся на элиотовскую эстетику, в которой это понятие занимает центральное место. «Nursery rhymes»
\end{abstract}


как терминологическая единица используется нами в оригинальном варианте, так как в любом русском переводе исчезает ее историко-культурный фон. В ходе работы в текстах поэта-модерниста нами были выявлены определенные признаки, характерные для произведений «nursery rhymes». Анализ специфики стихотворений данного жанра (игровая атмосфера текста, особый ритм и форма кодирования исторических событий, анималистические ракурсы, использование различных повторов и подражаний, создание окказионализмов и необычных имен героев и т. п.) подтверждает влияние традиции английской детской фольклорной поэзии на творчество Т. С. Элиота.

Ключевые слова: анималистика; поэтические циклы; рефрен; лимерик; сравнительные исследования; литературные жанры; литературное творчество.

Для иитирования: Маршания, К. М. «Популярная наука о кошках, написанная Старым Опоссумом» Т. С. Элиота в контексте традиции «nursery rhymes» / К. М. Маршания. - Текст : непосредственный // Филологический класс. - 2021. - Т. 26, No 2. - C. 191-199. - DOI: 10.51762/1FK-2021-26-02-16.

The concept of Tradition has always been crucial in T. S. Eliot's oeuvre. In his programmatic essay "Tradition and Individual Talent" (1919), included in his first collection of critical essays "The Sacred Wood. Essays on Poetry and Criticism" (1920), he claims that a poet must develop a conscious sense of the past and enrich it throughout his entire work. The famous modernist poet not only gives a definition for "tradition" but also emphasizes importance of historical background for writing and understanding poetry: "Tradition is a matter of much wider significance. It cannot be inherited, and if you want it you must obtain it by great labour. It involves, in the first place, the historical sense, which we may call nearly indispensable to anyone who would continue to be a poet beyond his twenty-fifth year; and the historical sense involves a perception, not only of the pastness of the past, but of its presence; the historical sense compels a man to write not merely with his own generation in his bones, but with a feeling that the whole of the literature of Europe from Homer and within it the whole of the literature of his own country has a simultaneous existence and composes a simultaneous order. This historical sense, which is a sense of the timeless as well as of the temporal and of the timeless and of the temporal together, is what makes a writer traditional. And it is at the same time what makes a writer most acutely conscious of his place in time, of his contemporaneity" [Eliot 1919: 55]. This idea of tradition, which requires a "historical sense" from the poet, was fundamental element of Eliot's aesthetic conception [Ushakova 2005]. Numerous examples of direct quotations,
For citation: Marshaniya, K. M. (2021). T. S. Eliot's "Old Possum's Book of Practical Cats" in the Context of "Nursery Rhymes" Tradition. In Philological Class. Vol. 26. No. 2, pp. 191-199. DOI: 10.51762/1FK-2021-2602-16.

allusions, a play with and around famous cultural events, names and themes indicate the poet's constant obsession of Literature of the Past and skillful inclusion of all this cultural arsenal of $\mathrm{Eu}$ ropean tradition into his own works interpreting these cultural elements in a completely new way.

One of these traditional elements Eliot was slick about in his verse cycle "Old Possum's Book of Practical Cats" (published by Faber and Faber Publishing House in 1939) was the English traditional folklore "Nursery Rhymes" (hereinafter - NR). This book of verse consisting of 15 poems conveys the style of children's fables, the originality of which is due to such characteristic features as playful atmosphere of the text, bright and funny characters, creation of an easy and casual conversation to the reader, a special rhythmic structure through the system of repetitions, specific lexical composition, etc.

Oxford Advanced Learner's Dictionary of Current English by A. S. Hornby gives the following definition of a term "nursery rhyme": "poem or song (usu traditional) for young children" [Hornby 1982: 72]. This term is translated into Russian as «детские песенки», «детские стишки», «потешки», «побасенки», «прибаутки» but all these versions of translation do not reveal its historical and cultural background. The British designate with this term all the variety of poems, songs, lullabies and counting rhymes for young children, which are passed down from adult generation to the younger one. However not every children's poem or any children's song deserve this glorious name (NR). As a rule, this term could be usually applied to very famous folklore works 
and more than one generation of native English speakers have been brought up on them. Some poems and songs of this genre had been created by certain authors but often in spite of universal fame and popularity their authorship was lost, and they acquired the status of folklore works.

Children's folk poetry inspired many outstanding English authors including such famous poets as Edward Lear, Lewis Carroll, Elizabeth Bishop, Robert Louis Stevenson, James Joyce and others. NR are an integral part of British culture and should be considered as the foundation of Nonsense and Absurd Literature. Their first appearance in English plays might be dated since the second half of the 16th century but they were widely recorded only through the $18^{\text {th }}$ century, when the emphasis in children's printed literature shifted from educational to entertaining [Fox 2000].

In the second half of the $18^{\text {th }}$ century the English Publishing House of John Newbery presented a collection of children's poems "Mother Goose's Melody, or, Sonnets for the Cradle" (1760). The title of this book was borrowed from a famous French author Charles Perrault who published the first collection of children's fairy tales under the title "Mother Goose's Tales" ("Les Contes de ma Mère l'Oie") in 1697 which later became very popular in France and out of the country. For every English reader a collocation "Mother Goose" evokes associations not with a palmate bird but recreates the image of a NR storyteller. Ulteriorly this concept became to be associated to children's folklore poetry in many countries.

The specificity of the comic mode in absurd poetry reflects the idea of philosophical approach to the foundations of the universe: if one tries to understand them it is necessary to turn them upside down. The texts of "Old Possum's Book of Practical Cats" and "Mother Goose Old Nursery Rhymes" naturally combine incompatible features in one character, phenomenon or object, using such artistic means as paradox, grotesque, paronymy. Nonsense is the game between a poet and readers that obeys special rules and requires items to play with. In this case these are words, structures, names of objects, characters' names.

In the works under consideration the things that cannot exist or occur in reality look funny and ironic. The comic mode manifests itself through absurdity. It is impossible for a cat to be busy about the house and feed mice with delicious dishes or to play the violin and wear gloves. The cat cannot be a famous illusionist as well as an old lady cannot live in a shoe, or cow cannot jump above the moon, and a little pig cannot eat roast beef for lunch. At the same time the playful nature of the poems allows their authors to reason on rather serious topics such as Religion, Philosophy, vandalism and crime, social inequality, etc.

Despite the playful tone of NR many scholars believe these rhymes had not been originally intended for children's audience. In her book "Real Personages of Mother Goose" (1930) Katherine Elwes Thomas provided an exploration of historical origin of the plots and heroes in many poems of this genre. She contributed the characters of famous NR to real persons and argued that those songs and poems not only carried an entertaining function but also represented a special form of coded historical stories looking as propaganda or protests [Elwes 1930]. This fact was also confirmed in the book "The Great Cat Massacre and Other Episodes in French Cultural History" by Robert Darnton arguing that famous "Mother Goose Old Nursery Rhymes" were created mostly to entertain adults. And later they were told for children to intimidate them. The author came to the conclusion that the majority of Nursery Rhymes did not reach the readers in their original form, strikingly different from those versions known among French peasants of the $17^{\text {th }}-18^{\text {th }}$ centuries. The original plots could frighten for their horrible details concerning rape and sodomy, incest and cannibalism. French storytellers of the 18th century did not hide their ideas under symbols. They bluntly portrayed the world full of terrible and undisguised cruelty [Darnton 1984].

As a link between the past and the present the nursery rhymes connect readers with people and events of the past with their society and culture and help to reveal the socio-cultural context. Hiding behind the playful manner Mother Goose's tales raise such issues as gender discrimination, class division, institutions of family and education, social structure and moral values [Kulshreshtha 2017].

However, it is worth noting that although many researchers consider $N R$ as political and economic allusions there is no direct evidence that they have been just only popular songs of their time. 
In this context it makes sense to consider the lullaby "Hush-a-bye Baby":

Hush-a-bye baby, on the tree top;

When the wind blows, the cradle will rock; When the bough breaks, the cradle will fall;

Down will come baby, and cradle, and all

[Rackham 1994: 14].

Samuil Marshak gives the following translation of these lines into Russian: «Баю-баю, детки / На еловой ветке. / Тронет ветер вашу ель - / Закачает колыбель. / A подует во весь дух - / Колыбель на землю бух!» [Marshak 2017: 39]. This nursery rhyme "refers to events preceding the Glorious Revolution. The baby in question is supposed to be the son of King James II of England, but was widely believed to be another man's child, smuggled into the birthing room to ensure a Roman Catholic heir. The rhyme is laced with connotation: the "wind" may be the Protestant forces blowing in from the Netherlands; the doomed "cradle" the royal House of Stuart. The earliest recorded version of the words in print contained the ominous footnote: "This may serve as a warning to the Proud and Ambitious, who climb so high that they generally fall at last" [Burton-Hill http].

"Goosey, Goosey, Gander" is another story that reflects the times of religious persecution when Catholic priests had to pronounce their forbidden prayers in Latin secretly, often in seclusion of their own houses:
Goosey, goosey, gander,
Whither shall I wander?
Upstairs and downstairs
And in my lady's chamber.
There I met an old man
That wouldn't say his prayers;
I took him by the left leg,
And threw him down the stairs

[Rackham 1994: 14].

«...Ясердитыйсерыйгусь, / Еслинадо-подерусь, / Потяну врага за ногу, / Подташу его к порогу, / Вниз по лестнице спушу: / Осерчаю - не прошу!» [Marshak 2014: 87].

The song "Ladybird, Ladybird, Fly Away Home" also has connotations related to the position of Catholics and their priesthood in Protestant England of the 16th century, who were burned at the stake for their beliefs: "Ladybird, ladybird, fly away home, / Your house is on fire, your children are gone..." [Rackham 1994: 69].
In Eliot's "Old Possum's Book of Practical Cats" the examples of this historical coding can also be found. For instance, in the poem "Of the Awefull Battle of the Pekes and the Pollicles":

And so they stepped out, with their pipers in order,

Playing When the Blue Bonnets Came Over the Border

[Ricks 2015: 19].

Волынщики их поспешили залиться

«Синими шапками на границе»

[Eliot 2013: 374].

These lines are devoted to the real Procession that took place during the Scottish uprising in 1715 . The fact is that throughout the $17^{\text {th }}$ century the English throne was the subject of heated battles between Catholic Monarchs and pretenders to the throne who adhered to their fathers' Reformed Faith. After the death of the Protestant William of Orange, a descendant of James II (who had been overthrown by William of Orange), re-entered Scotland. The devoted Catholic whose life goal was to convert England to the Roman Catholic Faith intended to create a monarchy based on the model of the kingdom of Louis XIV. He and his troops in blue Scottish Balmoral bonnets moved across the borders to London. The idea was to restore the Scottish Catholic Stuart dynasty to the throne. The uprising was suppressed, but the march survived all the later centuries, reminding even today of past rebellions and battles [Eliot 2012].

"Old Possum's Book of Practical Cats" is endowed with historical references to the Past and Present. The poem "Growltiger's Last Stand" is an allusion to the colonial problems of the British Empire. The title of the poem is associated with Custer's Last Stand at the Battle of the Little Bighorn in June 1876 which was the most prominent action of the Great Sioux War. Another example, referring to specific historical events is the phrase "Indian Colonel" from the poem "Gus: the Theater Cat", which hints at a period of history when part of the Indian subcontinent was ruled by Britain [Ricks 2015: 26].

Without going into details, it can be clearly seen that cats in Eliot's poems, like characters in "Mother Goose Old Nursery Rhymes", exist in different aesthetic paradigms and strata of society. Brilliant portraits of London inhabitants of the early $20^{\text {th }}$ century are presented in an ironic and satirical manner. Burglars Mungojerrie and Rumpelteazer and a criminal Growltiger are ex- 
cellent exponents of the lower strata of society, while Bustopher Jones is one of the representatives of the bourgeoisie. Different approaches to the development of feline imagery reflect different aspects of the poet's creative personality: a conservative ("royalist", "Anglo-Catholic" and a respectable bourgeois in everyday life) and at the same time an innovator, a "revolutionary" in art, a deep connoisseur of metaphysical poetry (a lover of the music hall and grassroots, popular culture of his time), etc. This issue deserves a separate consideration, but we will dwell on it in more detail in a separate study.

One of the remarkable characteristics of "Mother Goose Old Nursery Rhymes" and "Old Possum's Book of Practical Cats" is the anthropomorphism of the animals portrayed in the poetic texts. Animals are engaged into activities peculiar to human beings, they are surrounded by the objects from real human life, they can speak and thus express themselves. For example, a strict cat-mother and kittens from the song "Three Little Kittens" communicate with each other using a mixed human and feline language:

Three little kittens, they lost their mittens,

And they began to cry,

Oh! mother dear,

We very much fear,

That we have lost our mittens.

What! Lost your mittens, you naughty kittens!

Then you shall have no pie.

Mee-ow, mee-ow, mee-ow,

Yes, you shall have no pie.

Mee-ow, mee-ow, Mee-ow

[Rackham 1994: 16].

In Russian translation: «Потеряли котятки / На дороге перчатки / И в слезах прибежали домой: / - Мама, мама, прости, / Мын не можем найти, / Мы не можем найти / Перчатки! / - Потеряли перчатки? / Вот дурные котятки! / Я вам нынче не дам пирога. / Мяу-мяу, не дам, / Мяу-мяу, не дам, / Я вам нынче не дам пирога!» [Marshak 2017: 76].

This technique retains and conveys the main function of NR, which is to explain the laws of the surrounding reality and human society. In NR, as in children's poetry in general, there are practically no lyrics in its pure form. As a rule, children's poetry is focused not on the subject, but on the object, since the events taking place in the external world are of greater interest to children than the content of the poet's inner world.
However, Eliot's cats are not very talkative. In "Old Possum's Book of Practical Cats" only two of seventeen felines, Morgan and Gus, have voices and a reader can find the examples of their direct speech. "But from the title on, it is made clear that cats are just the topic of the poems, and cannot be, in any way, the major voice of the whole collection. Instead, Eliot's persona, Old Possum, is. Practical Cats is his book, and, in "The Naming of Cats", he repeatedly uses the I-pronoun as well as strong modal auxiliary verbs, such as "must" (v. 3-4), to establish his role as a guardian guiding us into the realms of a different species, like some sort of modern Orpheus" [Thiébaut http]. Thus, Eliot himself is hiding under the guise of Old Possum just as hundreds of storytellers stand behind the image of Mother Goose.

A special place in the animalistic world of "Old Possum's Book of Practical Cats" and "Mother Goose Old Nursery Rhymes" is occupied by cats who are presenting an important element of nonsense poetics. The world of cats in the British literary tradition is anthropomorphic and woven from paradoxes and absurdities. The images of English gentlemen and ladies can be easily detected in the habits and actions of furry heroes. Mother Goose's cats visit the Queen's Palace ("Pussy Cat, Pussy Cat, Where Have You Been?") and wear gloves. For small kittens as for many English children the worst punishment is to be deprived of pudding (pie) for dessert ("Three Little Kittens"). "Uncle" Eliot's cats (the poems were intended for his godchildren) are not inferior to folklore cats in a variety of life forms: Jellicle Cats arrange balls dancing a jig and a gavotte; Gus plays at the Theater; Bustopher Johnes goes to pubs, where he has a fun and samples the most exquisite dishes, or Mr. Mistoffelees, who amazes the audience with incredible tricks, etc. Nevertheless, not all cats have good manners and behavior. Sometimes they are reckless and lose those notorious gloves or playfully jump on a plum tree ("Diddlety, Diddlety, Dumpty"). Or like cats-thieves Mungojerrie and Rumpelteazer leave a chaos behind them reminding Oliver Twist and Jack Dawkins, the characters of the novel "Oliver Twist; or the Parish Boy's Progress; The Adventures of Oliver Twist" (1837-1839) by Charles Dickens.

Cats and nonsense writers get along with each other both in life and in books. It is well known that feline pets have always been Eliot's 
companions. It is no coincidence that cats played an intrinsic role in his works. Feline images are able to convey body language or character traits, in particular of women. A well-known Russian researcher of English poetic tradition Olga Polovinkina considering one of Eliot's poems «Whispers of Immortality» in her article "Someone Grishkin from a Poem by T. S. Eliot: a Poetic Impression of 'Russian Seasons"' states that the feline smell exuded by Grishkina shocks with its material density [Polovinkina 2011]:

The sleek Brazilian jaguar

Does not in its arboreal gloom

Distil so rank a feline smell

As Grishkin in a drawing-room [Eliot 1925: 57].

Eliot could also permit himself liberties and "theological eddies wander through the Possum book". According to Elizabeth Sewell, it makes sense for nonsense poetry to portray a cat like a "God, in miniature". She believes that GREAT RUMPUSCAT creates this very image. Thus, a mysterious and criminal cat Macavity can be considered a "devil in miniature" for an analogy. Eliot made no secret that he was a devoted fan of the famous writer Arthur Conan Doyle, so he was definitely inspired by Professor Moriarty, one of the main characters of detective stories about Sherlock Holmes. "Old Deuteronomy" (which is also the title of the last book of the Pentateuch of Moses, containing the last instructions of Moses, given to the Jews before his death) and "The Naming of Cats" where the author speaks about "cat's three names, one of which is ineffable" are also examples of these religious allusions [Sewell 1983: 71].

There is also a number of specific features such as rhyme, rhythm, meter, etc. that serve as confirmation for the fact that NR tradition is assimilated and continued in "Old Possum's Book of Practical Cats". Children's folk poetry is characterized by short lines with a small number of metric feet, as well as adjacent (aabb) and cross ( $a b a b)$ types of rhyme. However, the collection "Mother Goose Old Nursery Rhymes" presents a huge variety of other types of rhyme, for example, ternary (aabccb), as in the song "Rub-a-dub-dub" or triplet (aaa):

Cry Baby, Cry,

Put your finger in your eye.

And tell your mother it wasn't I [Rackham 1994: 50].
In "Old Possum's Book of Practical Cats" we can observe the diversification of stanza patterns (from quatrains to eight verses) and types of rhyme. The poems "The Naming of Cats", "The Song of Jellicles", "Old Deuteronomy" are based on the cross rhyme abab. "Growltiger's Last Stand", "Gus: The Theater Cat" are based on the adjacent (paired) rhyme $a a b b$ and in the poem "Of the Awefull Battle of the Pekes and Policles" a parallel "three-line" rhyme aaabbb is used.

One of the traditional genres peculiar for children's folklore poetry is a limerick. In Encyclopaedia Britannica a limerick is defined as "a popular form of short, humorous verse that is often nonsensical and frequently ribald. It consists of five lines, rhyming aabba, and the dominant metre is anapestic, with two metrical feet in the third and fourth lines and three feet in the others" [Encyclopaedia Britannica http]. For example:

Diddlety, diddlety, dumpty;

The cat ran up the plum tree.

Half-a-crown

To fetch her down;

Diddlety, diddlety, dumpty [Rackham 1994: 30].

This form can be found in the concluding part of Eliot's poem "Gus: The Theatre Cat":

These modern productions are all very well,

But there's nothing to equal, from what I hear tell,

That moment of mystery

When I made history

As Firefrorefiddle, the Fiend of the Fell

[Ricks 2015:26].

The first line of limericks traditionally introduces the name of a character and the place of their origin (mostly toponyms). The second line presents the actions or features of the character. The last line sets out the consequences of their actions or personal features. In early limericks the last line was often essentially a repeat of the first line, although this is no longer customary. A Russian author E. V. Klyuev remarks that toponym is usually rhymed with the most significant oddity which is the essence of the text of limericks so that readers should definitely get an impression that the place has an impact on a character [Klyuev 2000].

Eliot uses this peculiarity of a well-established traditional poetic form in his cycle but rather imitating Edward Lear who changed the traditional form placing the character's name in a strong position at the beginning of the line. Most 
poems in "Old Possum's Book of Practical Cats" are about a special member of the feline family. The author focuses readers" attention on the ima-ge of his character introducing a feline name in the title of a poem and necessarily indicating it in the first line. As for the place of character's origin the poet inserts cultural "inclusions" into his texts allowing a reader to guess it. Such places as St. Jame's Street, Bloomsbury Square, Pall Mall convey a particular meaning for an English-speaking reader evoking specific associative series, and also endowing the character living in these geographical realities with certain features.

Repetition system is another vehicle by which special melody and relation to NR are attained. Manifested at different levels (word, word combination, verse, the principle of depicting characters, etc.) this technique can be found in every poem of the cycle and thereby creates a holistic perception of the work.

The distinctive feature of almost all poems in "Old Possum's Book of Practical Cats" is a refrain, a bright stylistic device that also characterizes NR and nonsense literature. It is an important means of enhancing the emotional expressiveness of the work which focuses the reader's attention on the main idea of the text contributing to its rapid memorization. Refrains in "Old Possum's Book of Practical Cats" poems can occupy different positions in the text and their length varies from one line ("The Rum-Tum-Tugger") to six ("Old Deuteronomy").

Occasionalisms and onomatopoeia inherent in English children's poetic texts also contribute to convey rhythm and expressiveness. In Eliot's texts similar to many examples in "Mother Goose Old Nursery Rhymes" (for example, "Ding, Dong, Bell"), some occasionalisms have been built on the principle of sound associations, for instance, onomatopoeia "ker-flip, ker-flop" in a poem "Growltiger's Last Stand" (in Russian translations the analogues are "буль-буль" or "плюх-поплюх") [Eliot
1999: 19]. Another option is imitation of animal voices such as "mee-ow", "miow", "miew" and "purr" in a poem "Three Little Kittens" or "Wee, wee, wee!" in "This Little Pig Went to Market" [Rackham 1994: 16-17, 65]. There is only one example of this kind in "Old Possum's Book of Practical Cats": "Bark bark bark bark" in "Of the Awefull Battle of the Pekes and the Pollicles" [Ricks 2015: 18].

Eliot's tribute to Historical and Cultural Tradition of Nursery Rhymes can be recognized in his other works as well. The poet uses "London Bridge is Falling Down" in the postlude of "The Waste Land" where he personifies the bridge with Dante's limbo. This dark humor is also typical for English folk poetry.

Appeared centuries ago, as folklore, NR poetry was created to be read aloud. These poems impress the reader by their very sound. They possess a special magnetic musical rhythm which unites the poems from the "Mother Goose Old Nursery Rhymes" collection and Eliot's "Old Possum's Book of Practical Cats": they magically revive when they are recited or sung. It may seem that all these pieces of text are playful, light and non-intellectual, but the irony is in the fact that the most famous "nonsense" poems carry significant thought-provoking message.

Comparative analysis showed some similarities between "Old Possum's Book of Practical Cats" by T. S. Eliot and "Mother Goose Old Nursery Rhymes" compiled by A. Rackham. They are vivid animal images, outlandish word forms, resembling poetic structures and techniques such as limericks, refrain, etc.

Literary beasts in these works remind people in animal disguise and exhibit appearance and character features of the British. All parallels presented above allow us to conclude that the tradition of English nursery rhymes has a formidable impact on the poetic structure of "Old Possum's Book of Practical Cats" by T. S. Eliot.

\section{Литература}

Клюев, Е. В. Теория литературы абсурда / Е. В. Клюев. - М. : Изд-во УРАО, 2000. - 192 с.

Маршак, С. Я. Когда я стану королем. Английские детские песенки / С. Я. Маршак, А. И. Маршак. - М. : АСТ, 2014. - $178 \mathrm{c}$. $128 \mathrm{c}$.

Маршак, С. Я. Стихи и песенки Матушки Гусыни / С. Я. Маршак, А. И. Маршак. - М. : Росмэн-Пресс, 2017. -

Половинкина, О. И. Некто Гришкина из стихотворения Т. С. Элиота: поэтическое впечатление о «Русских сезонах» / О. И. Половинкина // Проблемы современной компаративистики / сост. Е. Луценко, И. Шайтанов. М. : Журн. «Вопросы литературы», 2011. - С. 230-241. 
Маршания К. М. «Популярная наука о кошках, написанная Старым Опоссумом» Т. С. Элиота...

Ушакова, О. М. Т. С. Элиот и европейская культурная традиция = Т. S. Eliot and European Cultural Tradition : монография / О. М. Ушакова. - Тюмень : Издательство Тюменского государственного университета, 2005. $220 \mathrm{c}$.

Хорнби, А. С. Толковый словарь современного английского языка для продвинутого этапа: Специальное издание для СССР. Т. II M-Z / А. С. Хорнби. - М. : Русский язык ; Оксфорд юниверсити пресс, 1982. - 528 с.

Элиот, Т. С. Книга о котах : в пер. В. Бетаки и англ. оригинале / Т. С. Элиот. - М. : Захаров, 1999. - 80 с.

Элиот, Т. С. Практическое котоведение // Т. С. Элиот ; пер. с англ. и коммент. С. Г. Дубовицкой. - СПб. ; М. : Летний сад, 2012. - 96 с.

Элиот, Т. С. Популярная наука о кошках, написанная Старым Опоссумом / Т. С. Элиот // Элиот Т. С. Стихотворения и поэмы / пер. В. Топорова, А. Сергеева, Ю. Рац. - М. : АСТ, 2013.

Burton-Hill, Cl. The Dark Side of Nursery Rhymes / Cl. Burton-Hill. - 2015. - URL: https://www.bbc.com/culture/ article/20150610-the-dark-side-of-nursery-rhymes (mode of access: 14.12.2020). - Text : electronic.

Darnton, R. The Great Cat Massacre and Other Episodes in French Cultural History / R. Darnton. - New York : Basic Books, 1984. -298 p.

Elwes, K. Real Personages of Mother Goose / K. Elwes. - Lothrop, Lee \& Shepard Co., 1930. - 360 p.

Eliot, T. S. Tradition and Individual Talent / T. S. Eliot // The Egoist. - 1919. - Vol. VI, № 4. September, December. P. $54-55,72-73$.

Eliot, T. S. Poems 1909-1925 / T. S. Eliot. - London : Faber \& Gwyer, 1925. - 99 p.

Encyclopaedia Britannica. - URL: https://www.britannica.com/art/limerick-poetic-form (mode of access: 15.03.2021). - Text : electronic.

Fox, A. Oral and Literature Culture in England, 1500-1700 / A. Fox. - Oxford University Press, 2000. - 202 p.

Kulshreshtha, Ch. Nursery Rhymes: A Linkage Between Society and Culture / Ch. Kulshreshtha // IJELLH. - 2017. -

Vol. V, Issue IX, September. - P. 13-22.

Rackham, A. Mother Goose Old Nursery Rhymes / A. Rackham. - Wordsworth Editions Limited, 1994. - 126 p.

Ricks, Ch. The Poems of T. S. Eliot. Volume II. Practical Cats and Further Verses / Ch. Ricks, J. McCue. - London : Faber and Faber, 2015. - 667 p.

Sewell, E. Lewis Carroll and T. S. Eliot as Nonsense Poets / E. Sewell // Eliot T. S. A Collection of Critical Essays / ed. by K. Hugh, Cl. Englewood. - N. J., 1983. - P. 65-72.

Thiébaut, E. Talking animals and talking cats in The Old Possum's Book of Practical Cats and its musical adaptation / E. Thiébaut. - URL: https://www.academia.edu/41829495/Talking_animals_and_talking_cats_in_The_Old_Possums_Book_of_Practical_Cats_and_its_musical_adaptation (mode of access: 15.12.2020). - Text : electronic.

\section{References}

Burton-Hill, Cl. (2015). The Dark Side of Nursery Rhymes. URL: https:/www.bbc.com/culture/article/20150610-thedark-side-of-nursery-rhymes (mode of access: 14.12.2020).

Darnton, R. (1984). The Great Cat Massacre and Other Episodes in French Cultural History. New York, Basic Books. 298 p. Eliot, T. S. (1925). Poems 1909-1925. London, Faber \& Gwyer. 99 p.

Eliot, T. S. (1999). Kniga o kotakh [The Book about Cats] / transl. by V. Betaki. Moscow, Zaharov. 80 p.

Eliot, T. S. (1999). Tradition and Individual Talent. In The Egoist. Vol. VI. No. 4, September, December, pp. 54-55, 72-73.

Eliot, T. S. (2012). Prakticheskoe kotovedenie [Practical Cat Science] // transl. by S. G. Dubovickaya. Saint Petersburg, Moscow, Letnii sad. 96 p.

Eliot, T. S. (2013). Populyarnaya nauka o koshkakh, napisannaya Starym Opossumom [Old Possum's Book of Practical Cats]. In Eliot, T. S. Stikhotvoreniya i poemy / transl. by V. Toporov, A. Sergeev, Yu. Rac. Moscow, AST. 605 p.

Elwes, K. (1930). Real Personages of Mother Goose. Lothrop, Lee \& Shepard Co. 360 p.

Encyclopaedia Britannica. URL: https://www.britannica.com/art/limerick-poetic-form (mode of access: 15.03.2021).

Fox, A. (2000). Oral and Literature Culture in England, 1500-1700. Oxford University Press. 202 p.

Khornbi, A. S. (1982). Tolkovyi slovar' sovremennogo angliiskogo yazyka dlya prodvinutogo etapa: Spetsial'noe izdanie dlya SSSR [Explanatory Dictionary of Contemporary English for Advanced Level: Special Edition for the USSR]. Vol. II M-Z. Moscow, Russkii yazyk, Oksford yuniversiti press. 528 p.

Klyuev, E. V. (2000). Teoriya literatury absurda [The Theory of Nonsense Literature]. Moscow, Izdatel'stvo URAO. 192 p. Kulshreshtha, Ch. (2017). Nursery Rhymes: A Linkage Between Society and Culture. In IJELLH. Vol. V. Issue IX, September, pp. 13-22.

Marshak, S. Ya., Marshak, A. I. (2014). Kogda ya stanu korolem. Angliiskie detskie pesenki [When I Become a King. English Nursery Rhymes]. Moscow, AST. 178 p.

Marshak, S. Ya., Marshak, A. I. (2017). Stikhi i pesenki Matushki Gusyni [Verses and Songs of Mother Goose]. Moscow, Rosmen-Press. 128 p.

Polovinkina, O. I. (2011). Nekto Grishkina iz stikhotvoreniya T. S. Eliota: poeticheskoe vpechatlenie o «Russkikh sezonakh» [Someone Grishkin from a Poem by T. S. Eliot: a Poetic Impression of "Russian Seasons"]. In Problemy sovremennoi komparativistiki. Moscow, Zhurnal «Voprosy literatury», pp. 230-241.

Rackham, A. (1994). Mother Goose Old Nursery Rhymes. Wordsworth Editions Limited. 126 p.

Ricks, Ch., McCue, J. (2015). The Poems of T. S. Eliot. Volume II. Practical Cats and Further Verses. London, Faber and Faber. 667 p.

Sewell, E. (1983). Lewis Carroll and T. S. Eliot as Nonsense Poets. In Eliot, T. S. A Collection of Critical Essays / ed. by K. Hugh, Cl. Englewood. N.J., pp. 65-72. 
Marshaniya K. M. T. S. Eliot's “Old Possum's Book of Practical Cats" in the Context of "Nursery Rhymes"...

Thiébaut, E. Talking Animals and Talking Cats in The Old Possum's Book of Practical Cats and Its Musical Adaptation. URL: https://www.academia.edu/41829495/Talking_animals_and_talking_cats_in_The_Old_Possums_Book_of_Practical_ Cats_and_its_musical_adaptation (mode of access:15.12.2020).

Ushakova, O. M. (2005). T. S. Eliot i evropeiskaya kul'turnaya traditsiya [T. S. Eliot and European Cultural Tradition]. Tyumen, Izdatel'stvo Tyumenskogo gosudarstvennogo universiteta. $220 \mathrm{p}$.

\section{Данные об авторе}

Маршания Кристина Михайловна - аспирант кафедры русской и зарубежной литературы, Тюменский государственный университет (Тюмень, Россия).

Адрес: 625000 , Россия, г. Тюмень, ул. Володарского, 6.

E-mail: christy-m@mail.ru.

\section{Author's information}

Marshaniya Kristina Mikhailovna - Postgraduate Student of Department of Russian and Foreign Literature, Tyumen State University (Tyumen, Russia). 